\title{
The Far Morocco Idrisid Arts and their role in enriching the plaster wall processing in the southwest Saudi Arabian kingdom in the century $\left(14^{\text {th }} \mathrm{AH} / 20^{\text {th }} \mathrm{AD}\right)$
}

\author{
DOI: $10.21625 /$ archive.v1i1.137
}

\section{Eman Ahmed Aref}

Lecturer in Art History Department - Faculty of Fine Arts - Helwan University

\section{Keywords}

Idrīsid dynasty, Idriss Palace, Jizan Area, Mulay Idris

\begin{abstract}
Studying the methods of plaster wall decorations is considered one of the complementary elements of the architectural vocabulary that reflects the cultural and ideological heritage identy of the time period. Wall decoration has broken the barrier of time and place, and the political and doctrinal differences, expressing in an abstract way the truth about the beilefs of both the Far Morocco Idrisid and Sebia Idrisid in kingdom of Saudi Arabia, where they did not use any symbol or sign that demonstrates their belonging to Shi'i Muslims, so-most probably- they belong to Sunni Muslims. This study aims to track the foundation phases of Idrisid state in Far Morocco during the century $\left(2-4^{\mathrm{TH}}\right.$ A.H/8-10 ${ }^{\mathrm{TH}}$ A.D) and its extension to the east in the Tihama Asir region during the century $\left(14^{\mathrm{TH}} \mathrm{AH} / 20^{\mathrm{TH}} \mathrm{AD}\right)$. The research problem lies in trying to detect the link and the nature of the relationship between the two states despite their differences in time and place through studying the natural strategic crossings, as well as the political circumstances that contributed in the transfer of the influences of Far Morocco Arts to Sebia region in the southwest of the Kingdom of Saudi Arabia, which contributed in enriching the plaster decorative arts of the facades of the Idriss Ashraaf's palaces, and their merging with the local artistic nature of Najd, Yemen. This study has revealed- through following the analytical descriptive method- the emergence of some influnces coming from the countries of East Asia and India and the countries of the African continent due to Sebia's geographical location as a port on the Red Sea and its presence on both the coastal trade way and caravans.
\end{abstract}

\section{Introduction:}

The Kingdom of Saudi Arabia has gained a religious sanctity for having the two Holy Mosques, as it is one of the first center of the initial planning of the Islamic civilization architecture in Asia and the world. It has influenced by previous arts, and civilizations; some of which are local whereas others are foreign. Arts were not important in the beginning in order to abide by the teachings of Islam, rejecting all aspects of Worldly Life as Worldly life is nothing but a place to work. And thus Art has become nothing but a secondary functional element. And the passage of historical epochs and the expansion of Islamic conquests across the Earth to spread the true religion of God, the arts of these countries have mingled with the Islamic values resulting in new arts with a distinguished character. Thus we find a similarity between the decoration units of the facades of Najd clay architecture with its traditional features prevailing in all parts of the Kingdom of Saudi Arabia and which are emotionally associated with Yemeni heritage - mingled with the spirit of the royal court's arts of the Ummayad and Abbasiyah Caliphates embodied in the palaces, mosques and Asbestos of the state of Aldarsa in Morocco, also the reign of the state of Adresse Gazzano has mingled with The art of decoration of Moroccan architecture, Andalusian and Indian architecture which resulted in new shapes of deep and hollow decorative units on the walls of some of the wealthy class houses in the late reign of the Ottoman Empire in Farasan islands located in the Red sea southwest Saudi Arabia. 
Statement of the Research problem:- An attempt to reveal the link and the fact that the relationship between the two countries belong to the Idrisid period in origin and supervision in both Morocco and Jizan in the Kingdom of Saudi Arabia, despite their differences in time and place and the scarcity of dealing with this topic.

The role of the natural strategic pathways, as well as the political circumstances that contributed in the transfer of the influences of Far Morocco Arts to Sebia region in the southwest Saudi Arabia, which contributed in enriching the plaster decorative arts of the facades of the Idriss Ashraf's palaces, and their merging with the local artistic nature of Najd,Yemen.

Research Objectives:- Follow the stages of establishing the Idrisi state in far morocco during the century (2$4^{\text {th }} \mathrm{AH} / 8-10^{\text {th }} \mathrm{AD}$ ) and the extension of its Ashraf eastward in the region of Tihama Asir during the century $\left(14^{\text {th }} \mathrm{AH} / 20^{\mathrm{TH}} \mathrm{AD}\right)$ to find the relationship that links them despite their differences in place and time as they are separated by nearly a thousand years.

Deducing and analysis artistic influences coming from Far Morocco, and its mingling with the local Najdi style that is reflected on the plaster wall processing in the remains of the Jizan Idrisid period in Sebia.

\section{Research Delimitations:-}

-Place Delimitations: Far Morocco Fez city, Jizan in Al-Makhlaf Sulaimani region that is located between southwest Saudi Arabia and northwest Yemen.

-Time Delimitations: The Idrisid dynasty period in the late Abbasiya state reign ( $5^{\mathrm{TH}} \mathrm{AH} / 10^{\mathrm{TH}} \mathrm{AD}$ ) extending to the second half of the Ottoman empire reign (13-14 $\left.4^{\text {th }} \mathrm{AH} / 19-20^{\mathrm{TH}} \mathrm{AD}\right)$

Research Assumptions:- The remains of plaster decorations in the facades of the Idrisid dynasty palaces in Jizan region are characterized by a special arty nature distinguished from the rest of Saudi Arabian parts, where the common local Najdi artistic styles embraced the Yemeni and African styles producing art is a special character.

Research Hypothesis:- The Geographic location of Sebia in Tihama Asir region was one of the elements of the plaster wall arts development in the Kingdom of Saudi Arabia, They met and met traditional local Najdian arts, and foreign art, and reflected on the facades of what remained from the ruins of some palaces and buildings of Idriss Rulers in Jizan.

The political circumstances also helped in the formation of the plaster decorations style which made it different and special in comparison to its counterparts in the same era.

Research Methodology:- This study follows the comparative analytical method which depends on some special repetitive elements on the walls of some of the remains of the Idrisid of Far Morocco and Sebia in Kingdom of Saudi Arabia.

2- Background History: The Arabian Peninsula and North Africa are linked through a long history, however research should extend to the depth of the historical Idrisid beginnings, especially that we are trying through this study to deduce the reasons for their relocation from the south of the Arabian Peninsula towards Far Morocco, and the return of their Ashraf a thousand years later to the place of their origin, which contributed in enriching the plastic decoration processing in the period of Jizan Idrisid dynasty in Tuhammet "Asir reigon.

2.1- The beginning of the Alawites' rebellion in the Arabic Peninsula: Al-'Alwain have suffered from the persecution of their cousins the Abbasiya Caliphate, where they believed that they had the right to rule the Islamic state, and so their rebillions reiterated to throw the Abbbasid state, beginning from Muhammed bin Abd Allah bin Alhasan who was called the "the pure soul" and his brother Ibrahim, but Abu Ga'far Al Mansour had confronted them in (145 AH/762 AD), and in the year (169 AH/786 AD) the Caliph Moses Al-Hadi bin Al Mahdi put down another Alawites' rebellion in the famous battle Alfakkh (the trap) near Mekkah (169 AH/786 AD), but Yahya and his brother Idriss were able to flee to Egypt disguised among the piligrim caravans, heading toward Morocco that included the two states of Kharijites (Tiaret and Sijilmasa) that were hostile to the Abassid state.

2.2- The foundation of the first top state by the Arab Morocco Idriss $5^{\text {TH }}$ A.H./10 ${ }^{\text {TH }}$ A.D: Al'Alwain Idriss were contemporary to both the Saffarid state in Sijilmasa city in Far Morocco, and the Rustamid state in the East, and it also became allies with the Ibadi state. The Rustamid state had supported the first establishment of the Idrisid state in respect to their Muhammed descendants, and it stood against the Abbasid attempts To eliminate them in a political manner in spite of " the Abassids present in Kairouan and their hatred and enmity to Idriss I and his family, and despite their multiple armies that were so big for Idriss I to figureht in his beginning... but they could not attack him for the fear of the Rustamid rebellion against them in support to the big Idriss"1 ( Muhammed Ali Daboz: 2010)1.

2.3- Idriss I (788-793AH): By the arrival of Idriss Bin Abdullah Al Kamel at Volubilis city which is related to Tangier according to the Roman administrative division, in the year (170AH/ 787AD) during Yazid Bin Hatem reign in 
Africa. Idriss I was able to address the Berber tribes beginning with Awraba tribe through their Sheikh Isaac bin Abdul Hamid the Awraban and Mawla Rashed,and to attract them with his ancestry back to the hashimi Prophet household , and to convince them with the independence from the Abassid state using their tribalism tendency, the Berber tribes continued to pledge allegiance to him such as Awraba, Zenata, Zwawa and others in the year (172 AH/790 AD ) declaring the separation of Far Morocco from Africa after the separation of Andalus, and thus he was could spread the Islamic religion. He tried to unite them under the umbrella of the first Moroccan state forming a strong army and taking advantage of the Berber tribes' marshal and war skills, unifying their populations languages into Arabic the Holy Quran language, and trying to keep the fabric of the society by eliminating tribalism.

The Islamic conquests succeeded in all parts of the Arab Morocco dominating Tamasna ${ }^{2}$ westward and Tlemcen eastward (173 AH), Their expansion westward worried the Khalif Harun Al Rasheed and made him decide to get rid of the Idrissid leader by his assassination in the year (177 AH/793 AD).

2.4- Idriss II (177- 313 AH/ 793- 828 AD): By the death of Idriss I, his servant Rashed took over, and then one of the Berber tribes leaders had taken care of Idriss II (177-313 AH/793-828 AD) until he grew and took rule. Fez city during his reign had become the lighthouse of knowledge and science of the Andalus region through Al Quaraouiyine and Andalus mosques which were built by workers from Andalus and Tunisia. So the Andalusian Axillary Rustumid, and Aghlabid taste mixed with the Moroccan taste had dominated, especially at the time of Andalusian emigration during the century ( $7^{\text {th }} \mathrm{AH} / 13^{\text {th }} \mathrm{AD}$ ) fleeing from the Christianization violence due to the weakness of the Almohad (the monotheists) under the reign of both the Hafsid and slavery states.

The rise of the Idrisid state in Far Morocco (172 AH/788 AD) coincided with the Axillary Rustumid state in middle Morocco (164 AH/781 AD), and the Aghlabid state in Africa (184 AH/800 AD), and thus the period of the governors that follow the Abassid state ended, (Hussein Moanis: 2000 AD) ${ }^{3}$. The Islamic conquests in Morocco were easy due to the likeness of the Berber's social nature to the Arabs' including tribal life and Sheikh.

\section{5- The struggle of the Ummayyad Caliphate and the Fatimid Caliphate in the Arab Morocco:} The figureht between the Ummayyad Caliphate in Andalus and the fatimid caliphate in morocco continued on ideological bases between Shiite and Sunnite, until the center of caliphate had moved to Egypt, as the Fatimid caliphate headed to open it, the Umayyad Caliphate took the chance to dominate all parts of Morocco. This struggle had resulted in rich civilized and cultural contact that reflected on all faces of social, scientific and cultural life. The Ummayyad Caliphate reign in Morocco and Andalus continued and ended in (422 AH/ 1030 AD).

The Fatimid Caliphate tried to spread Shi'ism in Morocco in the year (296 AH/908 AD), however the Maliki Imams rejected this, which exposed them to tyranny and torture, and they had to flee to Andalus and tried to consolidate the Maliki Sunii doctrine, however Shi'ism had spreaded in Morocco and Andalus in the Fatimid era in a limited way on the hands of the Sufi philosopher and jurist AbuAbdullah Muhammed Bin Abdullah Bin Mssara Bin Nagiih Al gabaly (269 AH/319 AD), and as the Fatimi's dream of spreading shi'ism in Morocco and Andalus didn not come true because of their people's adherence to the Maliki Sunni doctrine, the Fatimid Caliphate headed toward Egypt hoping to spread their doctrine.

2.6- The end of the Idrisid state in the Arab Morocco: When Idriss II began to divide the Idrisid state among his brothers as an inheritance, they fought over the reign which led to the weakness of the state, and also helped the Meroite Andalusian and Fatimid invasions to take over. Sometimes they invited the Idrisid Imams To the Fatimid Caliphate in the time of Al Qasem bin Al Hassan reign (337 AH/948 AD) to avoid their assault, and other times they invited the Sunni Andalusian Ummayyad to avoid their invasions, until this confusion and political weakness had ended in their complete elimination, and the Umayyad control (985 AD) over most of their cities and the Fatimid got rid of the last of their rulers.

3. The Expansion of Idrisid Ashraaf: The Ashraaf descendants continued supplementary in Morocco without being rulers; the most famous geography scientist appeared in $\left(5^{\text {th }} \mathrm{AH} / 11^{\text {th }} \mathrm{AD}\right)$ century, and $\mathrm{Al}$ Safadi called him Idris in his book AlWafi Bel Wafeyat,( the extensive book of the dead), according to his great grandfather, Mohamed Ben Mohamed Mohamed Ben Abdullah Ben Idris Ben Yahia Ben Ali, up to the sixteenth grandfather reaching Abu Talib. He was born in the Moroccan Sabta city in (493 AH/1100 AD) and died in (560 AH/1165 AD) His residence on the Mediterranean coast facilitated his movement among neighboring countries and Asia, recording their geography. Ibn Khaldon called him AlHamoudi, in reference to his granddad Hamoud, the founder of Beni Hamoud State, one of the descendants of Idrisis in Malga, Andalus in (407 AH). "Their ruling quickly extended to Algeciras, the Green Island, in (431 AH), and their rule was known as the Taifa Kings, Idriss I Rule” ${ }^{3}$ (Abdulghani, M. H., p. 7 \& 8 ) $^{4}$. They were known as Taifa Kings due to the conflicts that were among the Umayyad and the Hammudid Branch over the Caliphate of Andalus, as seditions spread during this period of time, which led to the breakdown of the Umayyad dynasty and the foundation of Taifa Kingdoms in (417 AH) under the leadership of Al-Mu'tali, the ruler of Malga Kingdom, and Mohamed Bin Qasem Al-Mahdi, the ruler of Algeciras in (427 AH). 
The name of Idriss, accompanied by an adjective, passed around the ancestry of Idrisid Ashraaf as in Morocco ( Idriss Al-Mutta'eyd, Idriss Al-Aali, Idriss Al-Sami), and their ancestery ramified among the Algerian Ashraaf, such as Al Sharif Abdelqader bin Mohi Aldin, the founder of the modern Algerian State resistant to the French colonialism (1808-1883 AD), and the Senussi Ashraaf in Libya and Al Jebel Akhdar (The Green Mountain) (1950-1969 AD), and Al Sharif Ali bin Mohamed in Jizan (1830-1943 AD).

4.1. The Geographical Location and its Civilizational Effect on Jizan Region: It is difficult to determine the beginning of the history of Jizan Region due to the lack of previous studies and archaeological excavations despite the importance of its geographical location that links it to Yemen, passing through Hijaz and extending east and northward. However, some historians maintain that its history goes back to pre-Islam as it was one of the destinations of prophet of god solomon to look for precious metals. They most probably reached this conclusion due to its proximity to the then contemporary civilizations of Moin and Sheba kingdoms. This region was also a contemporary of the reign of the kings of Humyar in Yemen and kings of Hijaz and Yamama, concurring with the era of old Arab kingdoms.

Jizan Region is characterized by the abundance of water and fertile agricultural land as well as its distinguished geographical location as it overlooks the Red Sea from the west, and it is close to the navigational road of the Bab El Mandab Strait, which is linked to the Arabian Sea. It shares borders with Yemen from the east and south and with 'Asir from the north.

In addition, Jizan Region lies on the two roads of commerce, pilgrimage, immigration, and wars, which are called Tihamah Coastal Road and Jadah Al Sultaneyah Al Wosta that lead to Yemen, Makkah Al Mokarama, Al Madina Al Monawara, Iraq, Bilad Al Sham, and Egypt. These two roads have enriched the civilizational relations and cultural ties among these countries and cities, transferring the treasures of their deep-rooted arts, such as the ancient Egyptian, Assyrian, Babylonian, Canaanite, and Hadramout arts, leaving their traces on the styles of plaster wall processors on the surfaces of architectural walls.

The geographical location has also aided in activating the sea and land trade and in enhancing the artistic mixture in the crucible of the previous ancient civilizations, especially after the arab islamic conquest, which led to the production of a new kind of plaster decorative arts with a special character that distinguishes the south western region of the Kingdom of Saudi Arabia during the second half of the $\left(13^{\text {th }}\right.$ AH/ $19^{\text {th }}$ AD) century.

4.2.The beginning of the Idrisid Ashraaf Era in Jizan: Prepare Al-Sharif Ali bin Mohamed bin Ahmed bin Idriss (1172-1253 AH/1758-1837 AD) is considered the grandfather of Idrisids in Tihamet 'Asir region as he is of Husseini origin, from the roots of the Idrisid Ashraaf in the Arab Morocco, and he is of the descendants of Bin Idriss, called Al-Asghar; Bin Idriss, called Al-Akbar; Bin Abdullah, called Al-Mahd Al-Kamel; Bin Al-Hassan Al-Mathni; Bin Al- Hassan Al-Sebt (Prophet Muhamad grandson; Bin Imam Ali Ibn Abi-Talib. And Ahmed- his grandfather, called Abi Al-Abass Al-Arachi, in the village of Maysoor in (1163 AH), and he learned the religious and juristic sciences in Kairouan Mosque, then moved to both Libya and Egypt, where there Al-Azhar Al Shareef, Sudan, and then to Makkah in (1213 $\mathrm{AH})$, where he stayed about thirty years. He learned at the hands of senior religion and jurisprudence scholars and kept guiding people to Allah, trying to spread his Sunni Sufi method that emphasizes the oneness of Allah, taking it from his mentor Sheikh Mohammed bin Abdul Wahhab (1115-1206 AH) Najd preacher who belongs to the doctrine of Imam Ahmed Ibn Hanbal. Therefore, the followers of Imam AbdulAziz bin Mohamed bin Masoud called it Wahabi as they entered Makka, but they ruled Makkah for seven years only, and then Mohamed Ali, the governor of Egypt conquered Makkah in (1228 AH), and Imam Ahmed Idrissi moved to Yemen, settling in the city of Sebya where he passed away in (1253 AH/1837 AD)

4.3. The end of the Idrisid Ashraaf Era in Jizan: Jizan Region suffered from resisting the Ottoman occupation, and in the mid ( $13^{\text {th }}$ AH $/ 19^{\text {th }}$ AD) century, Imam Mohamed bin Ali AlIdrissi (1293 AH/1876 AD) born in Sebya, Tihamat 'Asir- succeeded in regaining control over most parts of Mikhlaf Sulaymani along with its coastal ports till Serat and Tihamat Yemen.

Imam Mohamed is considered the first Azhar graduate to establish a state south the Kingdom of Saudi Arabia as he learned the religious and juristic sciences at the hands of great sheikhs and scholars from Al Azhar Al Shareef, Upper Egypt, and Libya where Imam Al Senusi was. A lot of tribal chiefs of Mekhlaf Sulaimani region, Yemen, Makkah, and Madina were attracted to him, and through whom he managed to confront the army of Imam Yahia, the governor of Yemen. He designated Sebya region as the capital of his state for about fourteen years, being assisted with the English and the Italians and their desire to eliminate the Ottoman Empire, which was at that time dominating most parts of the world.

After the death of Imam Mohamed bin Ali Al-Idrissi (1341 AH/1926 AD), some weak rulers took over, which invited Yahia- Imam of Yemen- to conquer them. Therefore, the Idrisids appealed for the help of King Abdul Aziz, and Makkah Treaty was concluded in (1345 AH/1926 AD) with Imam Al Hassan bin Ali bin Mohamed. However, Al Hassan, Jizan governor, did not continue his commitment to the treaty for several reasons, among which is the tension in the tribal internal political relationships, especially with Bani Aa'id tribe and the cupidities of Makkah governor, Al Shareef 
Hussein, from the northern side under the approval of King Abdul Aziz, and Imam Yahia from the southern side in Tihama region. This led to his breaching the treaty with King AbduAziz and his joining Yemen Imam, hoping in finding a way out of his state, which led the first Saudi State to confront the Yemeni invasion. This ended with concluding Al Ta'ef Treaty in (1353 AH/1934 HD) and keeping Jizan region as a part of the Kingdom of Saudi Arabia and giving up most of Tihama lands that were under the control of Yemeni Idrisids.

\section{5- The transition factors of the Andalusian and Moroccan arts towards Jizan in the Islamic}

era: Established the Umayyad state (41-132 AH/660-750 AD) laid the first bases of plaster art and wall sculpting, this art had developed in the Abbasid Caliphate (132- 447 HA/750-1519 AD) where it was outstanding with its three stages in Samarra region, the Islamic art in the Abbasid period had special features that distinguished it from the arts of the previous cultures, the most famous plaster building then was Hwayselat palace or plaster palace in the western side of Tigris valley, it was built by $\mathrm{Al}$ Mu'tasem.

Plastering wall art had witnessed a more developed stage in the Sassanid Persian era, where it covered most of the walls, both internal as in the linings of arches the Mihrab( the prayer chamber), the ceilings and the inner walls, and external as in the facades of the entries, the minarets, and the door and window openings, then the Seljuk Turks developed and enriched it with more plant branches.

The Umayyad Caliphate in Andalus was characterized by the plaster art, using some organic materials in its preparation such as egg yolk to be more resistant to climatic factors. The Umayyad Caliph was keen on” separating the Anti- Abbasid political matters in the east from the intellectual cultural matters" 4 (Eman Mahmmoud Hamadi\&Lateef Khalaf Muhammed: 2016$)^{5}$, aware that science is the basis of nations' progress, so scientists in all fields had been sent to Baghdad to learn more, and thus Cordoba had become the intellectual and cultural capital in the Islamic west as a result of the mutual delegations' exchange among eastern and western scientists and therefore reflected on the artistic taste in Andauls where the splendor and the beauty of the plaster wall decorations of its palaces had matched those of Abassid palaces,and in this pattern the Andalusian taste transfered to Fez city the capital of the Idrisid state in Far Morocco, mingling with the arts of the Berber tribes whose ancestors extended in the African desert, mingling with the people of the Nile Basin; especially Nubia and Sudan, and through them the Andalusian Moroccan artistic taste had moved across the Red Sea extending to the southern and western parts of the Arabian Peninsula.

It is worth mentioning that in the Far Morocco Idrisid era, science was taken care of schools universities and libraries were established, the number of scientists increased and they became more keen to receive knowledge from different countries, in the east and west. Thus the Moroccan artistic character had crystallized and gained special features that distinguished it as a result of the social and intellectual contact.

The Abassid plaster decorative arts also moved to Far Morocco through Egypt, where ahmad bin tulun mosque had copied the Samarra style in wall decorations, gowns, Plant and Quranic streaks extending on the frames of the arches and the pillars' crowns.

This decorative style had particularly moved to Al Quaraouiyine Mosque in Fez and to Andalusia. It is worth mentioning that Far Moroccan arts in their beginnings were loyal to the Ummayyad eastern arts and also their cultural and civilization heritage prior to the Islamic conquest to the Old Egyptian, Aramean, Phoenician and Yemeni cultures, it should be mentioned that "Mawla Idriss the great, the founder of the first Islamic Arabic state in Morocco and his entourage had written with the eastern pen" ${ }^{5}$ (Ismail Ottoman:1992).

6- The plaster wall inscription technique: Craft engraving tools have evolved on plaster, using stone engraving and hollowing by knife and some pointed tools, and sometimes using casting models and fixing them on the walls. A community of skilled manifacturers and labourers did this artistic work each with a specific role to do, some were specialized in plaster preparing by mixing and purifying it from debris, while others spread it on the walls, and others drew motifs using some geometric tools and a sac containing ground for lining the motifs, and the decorator who the drawings using the engraving tools, succedded by someone who retraced the borders, the angles and the lines of the high relief and low relief shapes, and sometimes a painter was used in painting the plaster shapes with light and dark colors and sometimes gilding them with specific oxides.

The plaster treatments differed from one region to another according to the raw material availability and the financial potentials, however, it was proven that plaster material was used as an isolating and adhesive material in building bases throughout the world through history, also as a stucco to cover and isolate the wall in hot and cold atmospheres in summer and winter.

7- The Characteristics of plaster decoration art in Far Morocco: It seems that this art was influenced by the arts of the Egyptian culture in the constructional method of Engineering, we can also notice the usage of the curved Romanian arches that looked like the triumphal arches at the Romanian and the Ancient Greece city gates which were built with bricks or stone blocks as in (figure.1) they were characterized with their curvature and binding taking the shape of a horseshoe, sometimes the key stone extended in a tapered shape (figure.4), the broken arches were also used, with its sides stabilizing on stone stanchions, those arches were surrounded by plastic geometric plant plaster motifs mostly 
containing asterisk plates that were transmitted from the Berber arts. The kufic and thuluth calligraphy streaks were used, as in Mawlay Idriss IIzaywya (small mosque) (figure.4) as a new type of wall decoration which gave the wall a creative and distinctive character.

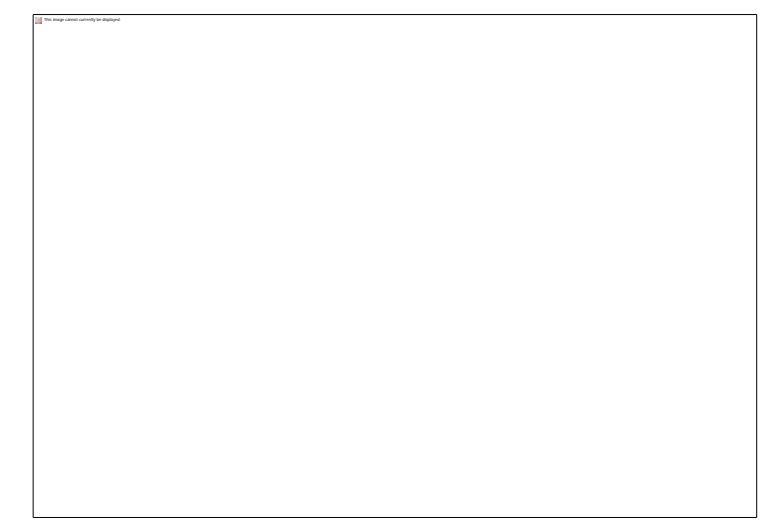

(Figure. 1) Mawalay Idriss IIzawya, the arches are horseshoe shape, Fez city, (5 $\left.5^{\text {th }} \mathrm{AH} / 10^{\text {th }} \mathrm{AD}\right)$ century

The Amazigh heritage of art is mixed (Figs.1\& 4) had mingled with the Byzantine and Romanic art, due to the proximity of Morocco to Constantinople, the plaster artist had replaced the mural engravings that were scattered in royal palaces and temples with the hollow plaster, he also utilized the minute plaster motifs through colouring it as It was a piece of mosaic. The plaster decorations had varied between low relief and high relief, and between grooved and hollow, mixed with various textures and materials, like the colored ceramic tiles, and the engraved wood, which added to the plaster material a unique special character in color and processing, which led to the aesthetic unity between repetition, harmony and solidarity between the decoration units, the various materials and the architectural wall.

The decoration of mosques and palaces was not a priority for the Muslim artist as it was in the previous artistic civilizations, applying Arabic language (the language of Qura'n) as the main language, enforced Islamic people unity and ended the tribalism and the tribal differences, which reflected on the unity of the Islamic arts and the domination of the true religious teachings, thus producing artistic styles in all parts of the Islamic world. This is applicable to the Far Moroccan Idrisid dynasty that established the Islamic belief in the Berber tribes' spirits, and involving them in the Islamic conquests in the east and west.

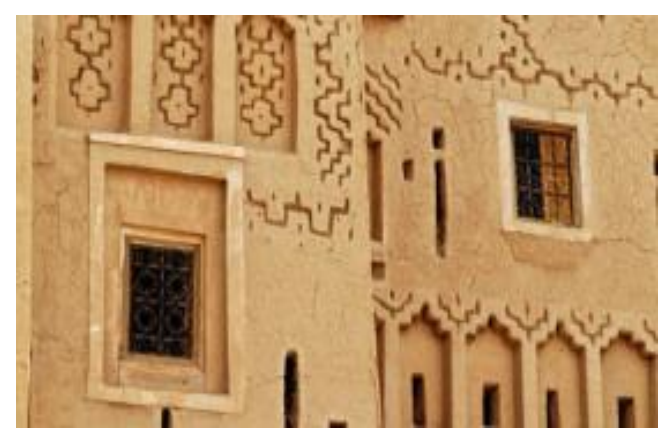

(Figure.2) some of the Amazing's decorations in the farm houses that where common since ancient times

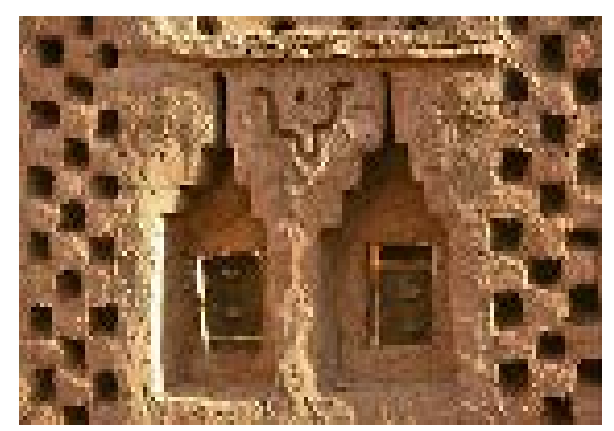

(Figure.3) some of the wall decorations in one of the facades of the Berber towns.

The artist had created genuine plaster decoration elements, inspired by the artistic amazighs heritage units (Figs.2\&3) which were spreading on the clay houses' walls in this period, mixing them with the artistic experience that he carried with him since he moved from the south of the Kingdom of Saudi Arabia to Far Morocco, and thus appeared the high relief and low relief lines, and decoration units coming from both heritages mingled with the Ummayyad and Abbasid styles and the inherited arts in this region. 


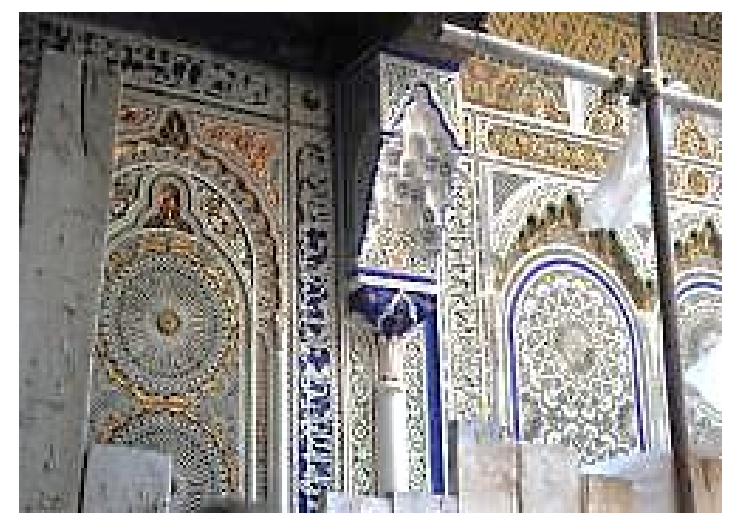

(Figure. 4) a detailed plaster decoration in Mawlay Idriss II Zawya, Fez city, (5 $\left.5^{\text {th }} \mathrm{AH} / 10^{\text {th }} \mathrm{AD}\right)$

The Muslim artist was skilled in at geometric and arithmetic sciences, inspiring from the asterisk plates in the Barbaric heritage arts, many innovative polygonal forms of asterisk plates (fig. 4) as in Mawlay Idriss II Zawya in Fez city. The plaster artist also dealt with the units of the wall decoration elements such as those used in the window openings (sunshades) which became similar to the solid wall windows, decorated with curved broken arches with stalactites, pillars and calligraphic streaks, showing his creative art meticulously through his skilled evacuation of the decorative units, and painting some of them with bright red, blue and golden colors.

The plaster artist in the Idrisi era was inspired by some of the Barbaric art features which were characterized by the higher relief elements, and he filled them with plastic geometric decorations,thus his plaster motifs looked like an extending mesh on the surface of the wall, stressing on the light and dark reflection, using different colors on the white plaster surface.

\section{8- The characteristics of the plaster decorative art in Sebia city:}

Imam Muhammad bin Ali al-Idrisi founded Sebia city in the year (1338 AH) as it was located on the north-eastern part of Jizan city. It was divided into two partitions, the old city and the new city near the Red Sea coast.

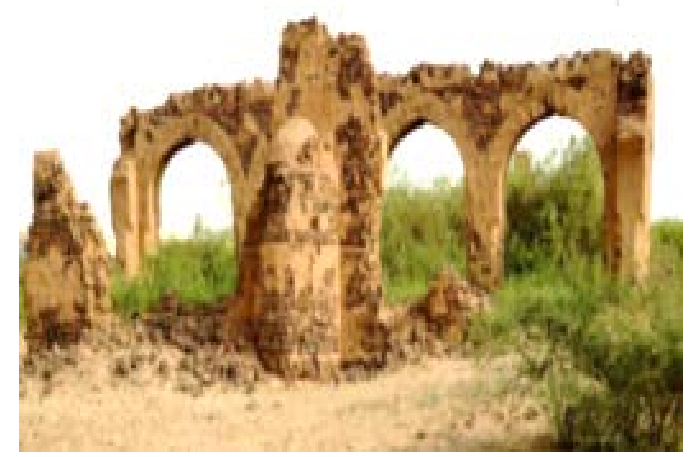

(Figure. 5) Ahmed bin Idriss Mosque in Jizan $14^{\text {th }}$ A.H/ $20^{\text {th }} \mathrm{AD}$

The architecture of the Idrisid palaces in Jizan belonged to the buildings of the second half of the century (14 $\left.{ }^{\text {th }} \mathrm{AH}\right)$, and despite of the wars that took place during this period, it was characterized by flat constructions that did not exceed one floor in the private houses, and stressing on the decorations of the facades and the low narrow and wide windows, and it was surrounded by walls and high castles with high gates (Fig. 5) in the form of horseshoe arches decorated with plant and geometric decorations and heritage asterisk plates.

The plaster decorations on the facades of the Idrisi buildings in Morocco were distinguished from their counterparts in Yemen, where they were closer to the Ummayyad era's decorations, and specially Samarra's arts in the Abbasid era, in the hollowing style and taking care of the facades and covering them with modified plant decorations.

Those new approaching influences were mingled with the Najdi heritage arts that were spreading around all parts of the Arabic peninsula, thus the elements of this heritage parts appeared in a regular and embellished way, following the occupation of the royal class artists, mingled with the Persian, Asian, and African spirits (Figs.6, 11\& 12) the decorated friezes included a collection of geometric decorated hollow elements made of clay and plaster, where they topped up the facades of the palaces and houses, especially the main gate that was specified for the visitors' entry and the two side windows located on the facade. 


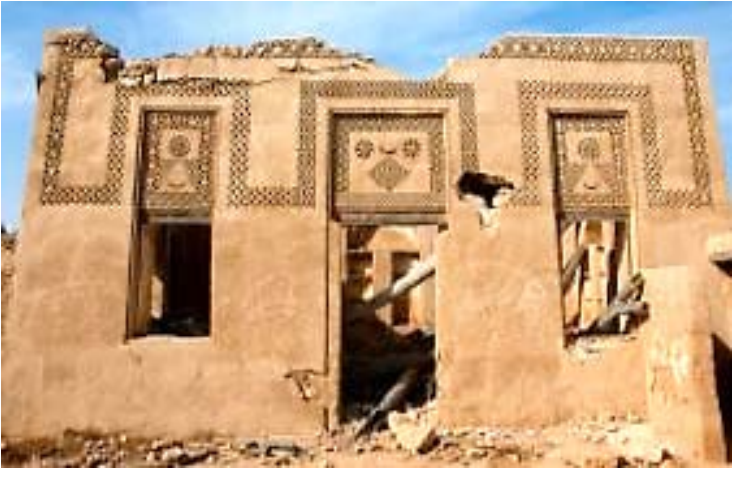

(Figure.6) Najdi style decorated plaster, the idrisid period $14^{\text {th }}$ A.H/ $20^{\text {th }}$

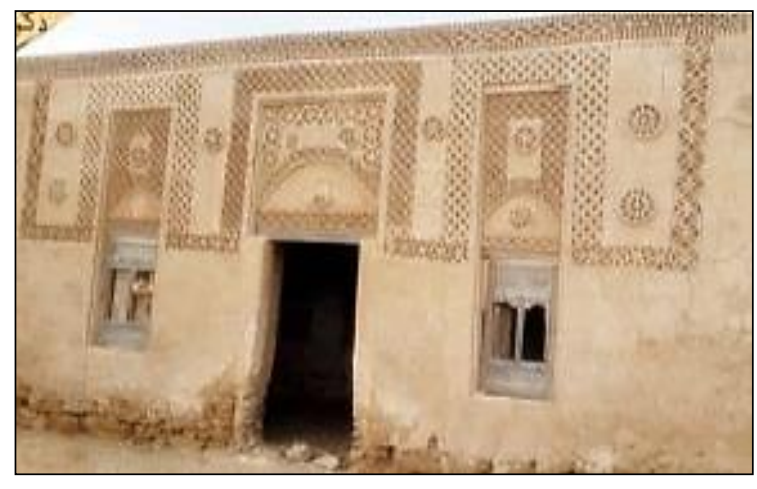

( Figure.7) a palace from the idrisid period in the late Ottoman era in Jizan. $14^{\text {th }}$ A.H/ $20^{\text {th }} \mathrm{AD}$

The plaster artist had selected his elements among the Najdi decorations, he didn't transfer them in their common usual outline that depended on the decorations of balconies, window openings and doors with plaster material, but he handled them in a method that was consistent with his ideological goal, through abstraction and refinement while keeping his special character. For example, he used "the triangular shape which was known as the Louhuj" ${ }^{6}$ (Abdullah bin Ibrahim Al Ameer:2007) ${ }^{7}$. Known as the name of glaucoma or the hollow opening penetrating the wall, in the form of triangles that were used as louvers and light slots in the windows of the Najdi buildings. The plaster artist in the Idrisi period used them as a kind of engraved decorations on the wall surface without penetrating it.(Figs.6,7\&8), he also used the Najdi decorative elements inspired by the palm leaves, and flower petals that were used in the decoration of the inner and outer balconies and which were known as Zaranik decorations and hollow balconies. (Figs.8,9,12,13\&14) the plaster adorned artist had used the artificial hollow engraving without penetration while showing the elements on the same level of the wall.

The artist kept the visual and architectural modelling as in (Figs.6\&7) through keeping the horizontal and vertical lines of the plaster friezes with the straightness of the constructive architectural modeling, while keeping the harmony and the diversity through breaking the repetition of the broken interlacing and curved lines harmoniously and finding solid solutions for the wall surface in a balanced way. The Jizan Idrisi processing of plaster decorations were not as sharp and hard as those of Far Morocco, as it was concordant with the wall, more gradient and low relief (Figs.7,8,9,10,11,12,13\&14) rather than being high relief and obtrusive on wall surfaces as in Far Morocco (Figs.1,2,3\&4) This was probably due to the proximity of Sebia from the sea coast that had the features of the Red sea arts which were characterized by frescos more than high relief plaster wall decorations, except in some African regions such as Kenya and Nigeria. However the Najdi character had dominated this region, and the Najdi artist kept the nature of wall paint that resembled the paint of the desert and natural rocks.

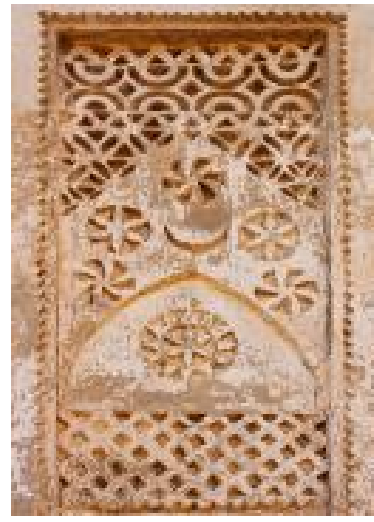

(Figure. 8) Decorated plaster in the Najdi style, Idrisid era $14^{\text {th }} \mathrm{AH} / 20^{\text {th }} \mathrm{AD}$

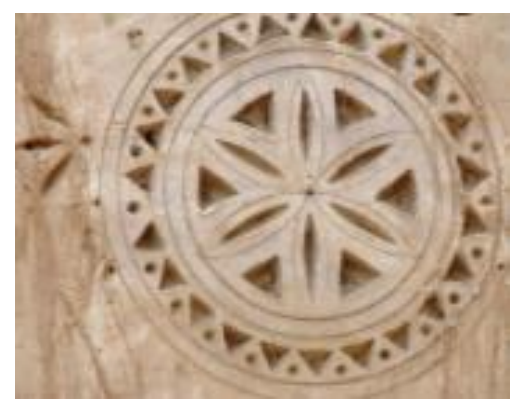

(Figure. 9) A plaster decorated unit common in the heritage architecture using the Najdi style

The artist kept in the Idrisi state period had kept the heritage character that distinguished Jizan region and despite being influenced by previous arts, he was able to incorporate between the different artistic styles, and thus appeared the asterisk plates with the high relief hexagonal and pentagonal petaled ornaments that were shaped inside low relief circular 
figureures (Figs.7,8\&9) and sometimes surrounded by frameworks of various hollow triangles in geometric regularity (fig. 9)

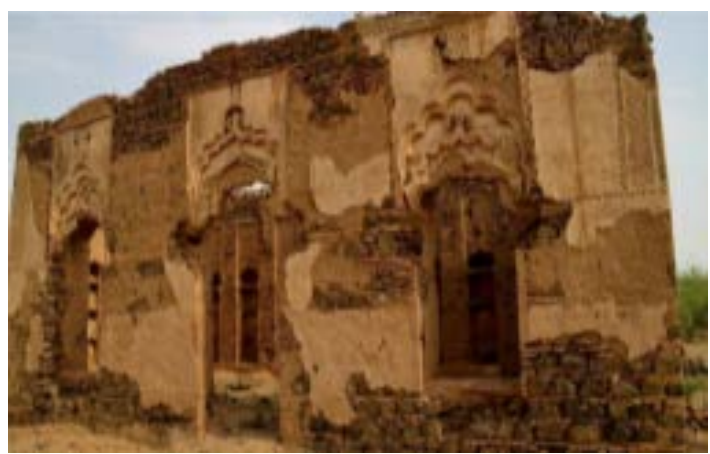

(Figure. 10) A detailed Palace multi-level broken arch $\left(14^{\text {th }} \mathrm{AH} / 20^{\text {th }} \mathrm{AD}\right)$

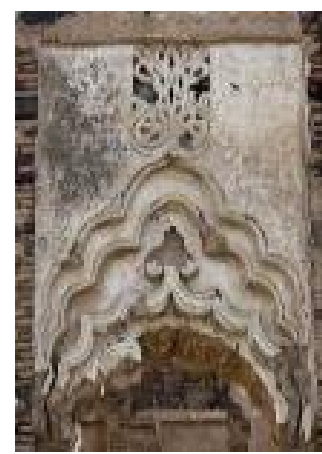

(Figure. 11) A multi-level broken arch at an Idrisid Idrisid palace $\left(14^{\text {th }} \mathrm{AH} / 20^{\text {th }} \mathrm{AD}\right)$

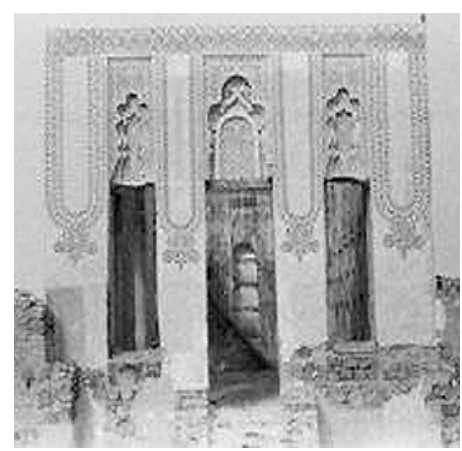

(Figure. 12) A façade of an Idrisid House in Jizan $\left(14^{\text {th }} \mathrm{AH} / 20^{\text {th }} \mathrm{AD}\right)$

The architect was not approved at that stageon using the architectural arches as much as shaping the wall decorations in hollow and decorated arches, keeping the simplicity of the primary lines of architecture as in (Figs..7,8,10,11\&12) thus the arches looked solid suggesting door and window slots on the full length of the facades and its greatness. The facades of the Idrisi palaces were designed as a main door located at the front of the building front characterized by its height, and located in the middle between two narrow windows that nearly the same height and were located on both sides, and it is thought to be the influence of a Turkish design, it spread in different parts of the Arabic peninsula such as AL Riyadh, Jeddah and Medina where a frontal area was added to it to sit in during summer.

As the wall processing of the Idrisi palace facades developed, the decorations with the straight frames developed into curvatures and also broken arches with Asian Persian character were added to it, on the summit of the entries and the windows of these palaces. (Figs.10,11\&12) As many and multiple of these contracts and differed in their layers, thus achieving a creative aesthetic value that was not common in this region. The plaster wall decorations took the spirit of the broken arches design and dropped down on its sides, which enriched the visual wall processing through the diversity of high relief and low relief in an alternate way, with breaking the barrier of the straight constructive and building lines that made up the building, we notice in (Figs.10,11\&12) the similarity between the broken arches in Sebia's palaces by those of Mawlay Idris II particularly at the top of the keystone (fig. 4).

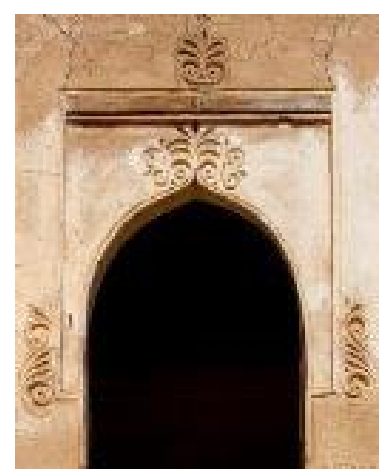

(Figure. 13) A Najdi style decorated plaster, Idrisid Era $14^{\text {th }} \mathrm{AH} / 20^{\text {th }} \mathrm{AD}$

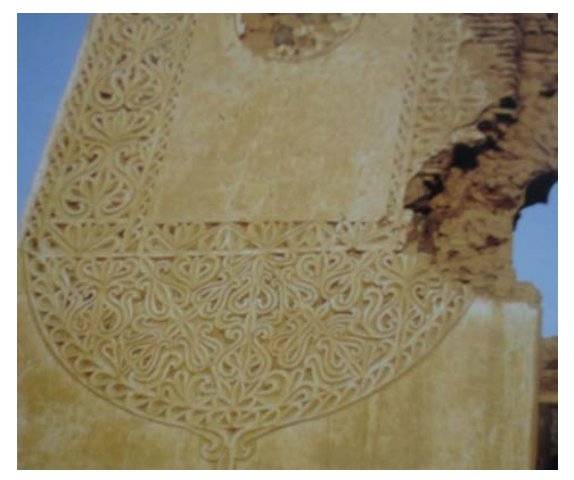

(Figure. 14) Details from the gate at Sebya, Idrisid Era $14^{\text {th }} \mathrm{AH} / 20^{\text {th }} \mathrm{AD}$

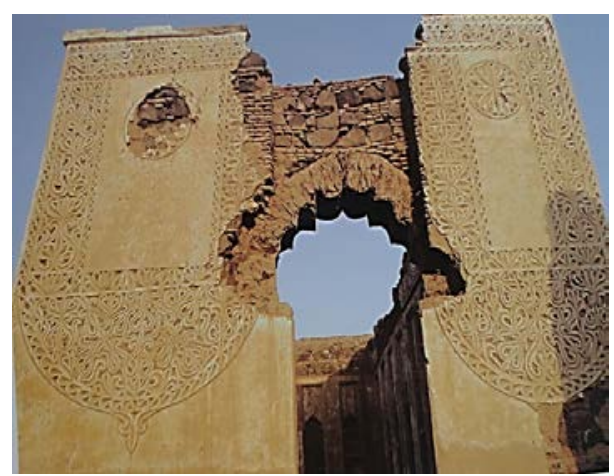

(Figure. 15) A city gate at Sebya, Idrisid Era $14^{\text {th }} \mathrm{AH} / 20^{\text {th }} \mathrm{AD}$

The plaster artist used the heritage plant units as the palm leaves decorations which were common on the facades of the heritage building (fig.13) as plastic units for the ornamentation of the arch summits which were ornamented in a simple and symmetrical form, he modified this decorative unit using curved and abstract lines which were thin and simple.the facades' decorations of the building entries had evolved and were taken care of, influenced by the style of the triumphal gates of the Romanian and ancient Greece buildings,consequently it looked higher and more refined, he also created in the decorative arts where he took care of the arches modeling resulting in the disappearance of the quadrilateral slots which were common in the very beginnings of the Idrisi architecture, thus the arch slots widened, he also took care of the wall plane motifs which were ornamented with vermicular decorative streaks, influenced by the Andalusian decorative style (fig.14) in its duality and arches duplication, also the Sasanian and Indian influences appeared in the wall decoration style, thus it appeared as dropdown curtains like the Indian and Persian rugs that were used in the formal celebrations. 
Those decorations extended from the building summit and ended in plant motifs that looked like rattles, mostly inspired by the Ottoman and barbaric heritage plant motifs.

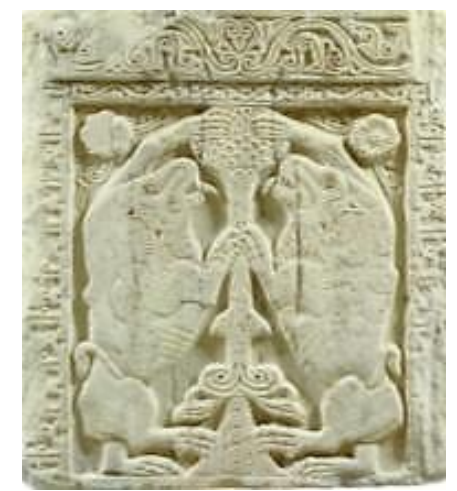

(Figure. 16) A granite slab from the Byzantine era, engraved with decorative units (11-12 AH) Christian and Byzantine Museum

The plaster decoration elements had mixed between the local style, which relied on the geometric abstract figureures, and the plant units with their interlacing branches with the artistic methods coming from India, Persia and Arab Morocco through bringing the skilled Manufacturers.

The plaster attractive elements of the ruins of Idrisid palaces and buildings were similar to those of the Umayyad's in the plaster engraving and hollowing method after drying and the motifs protrusion from the background with twisting and interlacing plant lines to cover most of the wall surface. However, the Idrisid motifs in this stage were formed of a group of plant stripes hollow in the insides and all around, also the decorative design was formed of wide and hollow plant stems surrounded by a frame formed of a part of this foliate heads,it also showed a multi-petaled flower that appeared in the Fatimid and Abbasid motifs and moved to the heritage architectonic style in Najd region, it is worth mentioning that in the primary stage some motifs of the Sasanian and Byzantine art methods overwhelmed (fig.16).

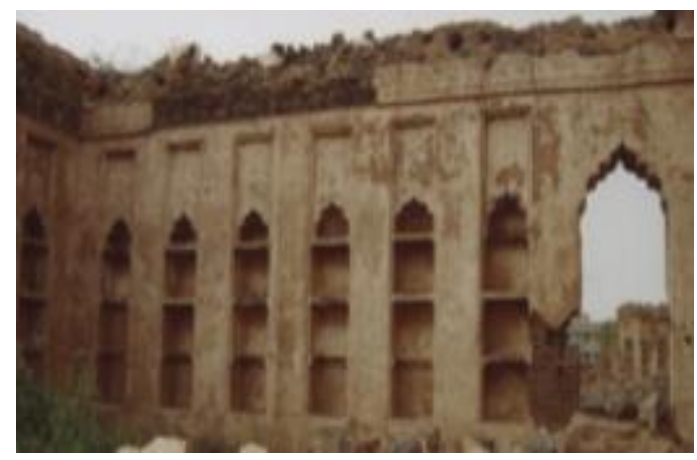

(Figure. 17) Inner wall closets with broken arches, an Idrisid Palace $14^{\text {th }} \mathrm{AH} / 20^{\text {th }} \mathrm{AD}$

The Idrisi buildings contained a collection of solid wall closets known " as Al faregha"(Abdullah bin Ibrahim AL Omair 2007) ${ }^{8}$ that looked like small window engraved in the wall, and which was used in keeping the household, lanterns, books and other things.

The Indian and Sessenian architectural arts reflected especially on the pointed arches that ornamented the inner and outer walls of the Idrisi architecture, and appeared on the top of the entrances' summits and the wall closets (fig.17), the decorations of some facades in Tihama Asir during the Idrisi era were sometimes characterized by their similarity with the Nubian decorations, where the solar asterisk plates and the straight streaks that lined the edges of the building facade and above the slots, which were formed of the hollow rhombus shape (Figs..6,7,8\&9).

\section{A comparison between the artistic method of plaster processing in both Far Morocco (Fez) and Jizan (Sebia):}

Both Abdel Rahman bin Mu'awiya bin Hisham (113-172 AH/731-788 AD), and Mawla Abdulla Al Idrissi were able to seize parts of Far Morocco and Spain, during the peak of the Abbassid caliphate stability, taking advantage of their preoccupation in wars, their eastern expansions and their bonds consolidation in all parts of the Islamic states, which gave Mawla Abdullah Al Idrissi a chance to found his state in Far Morocco through the polarization of some countries, such as Egypt, Libia, and Algeria, through his confidential messages based on his ancestry back to the Prophet household, thus deserving the Islamic caliphate more. On the same pattern, Jizan Idrisid Ashraf were able to find their emirate during the preoccupation of the Abbasid caliphate in their dispatches to consolidate their control over the trade and pilgrimage routes. 
Eman Ahmed Aref / The Academic Research Community Publication

(Figure.17) a comparison between the idrisi emirate in both Far Morocco and Jizan in the kingdom of Saudi Arabia

\begin{tabular}{|c|c|c|}
\hline Point of comparison & $\begin{array}{l}\text { The plaster decorarations of Far } \\
\text { Moroccan Idrisid }\end{array}$ & $\begin{array}{l}\text { The plaster decorations of Jizan } \\
\text { Idrisid }\end{array}$ \\
\hline The period & $\left(5^{\text {th }} \mathrm{AH} / 10^{\text {th }} \mathrm{AD}\right)$ & $\left(14^{\text {th }} \mathrm{AH} / 20^{\mathrm{TH}} \mathrm{AD}\right)$ \\
\hline $\begin{array}{ll}\text { Slitting } & \text { and } \\
\text { discharging tools } & \end{array}$ & Caliper and Ruler & Caliper, Rope and Knife \\
\hline $\begin{array}{l}\text { The dominating } \\
\text { feature }\end{array}$ & Luxury and Accuracy & Austerity and simplicity \\
\hline $\begin{array}{l}\text { The heritage artistic } \\
\text { influences }\end{array}$ & $\begin{array}{l}\text { The Berber arts, especially the old } \\
\text { Amazighs arts }\end{array}$ & The African and Najdi arts \\
\hline $\begin{array}{l}\text { The pre- } \begin{array}{r}\text { Islam } \\
\text { newcoming artistic } \\
\text { influences }\end{array} \\
\end{array}$ & $\begin{array}{l}\text {-Were affected by the Hellenistic, } \\
\text { Byzantine and Sasanian arts that melted } \\
\text { with the Umayyad arts } \\
\text { - The Romanes, Byzantine and Gothic }\end{array}$ & $\begin{array}{l}\text { Were influenced by the Hellenistic and } \\
\text { Sasanian arts. }\end{array}$ \\
\hline $\begin{array}{l}\text { The contemporary } \\
\text { artistic influences }\end{array}$ & $\begin{array}{l}\text {-Were influenced by Ummayyad } \\
\text { Damascus through the polarization of the } \\
\text { labourers and manifacturers from the east. } \\
\text { - The Andalusian and Aghlabids arts, and } \\
\text { the Indian arts through pilgrimage,trading } \\
\text { and wars. }\end{array}$ & $\begin{array}{l}\text {-Were influenced by the Abbassid } \\
\text { arts, where Sammara arts were. } \\
\text { - Zaidyyah arts, Asian, Indian and } \\
\text { Turkish arts through pilgrimage,trading } \\
\text { and wars }\end{array}$ \\
\hline $\begin{array}{l}\text { Decorative } \\
\text { eents }\end{array}$ & $\begin{array}{l}\text { - The abstract plant units with their twisting } \\
\text { branches were used, and the shapes were } \\
\text { fragmented and abstracted into geometrical } \\
\text { elements and they were reshaped } \\
\text { producing a replicated shape that gave the } \\
\text { continuity to the visual modeling. } \\
\text { - The decoration elements protruded from } \\
\text { the wall. }\end{array}$ & $\begin{array}{l}\text { - The plaster artist depended on the } \\
\text { interlacing straight geometrical lines, } \\
\text { and also on the abstract plant units, and } \\
\text { he didn't intentionally covered most of } \\
\text { the wall, thus his shapes looked simple. } \\
\text { - He kept the decorative elements in the } \\
\text { same height with the wall. }\end{array}$ \\
\hline The asterisk plates & $\begin{array}{l}\text { He took from the Barbaric art the asterisk } \\
\text { plates modeling,and added to it. }\end{array}$ & $\begin{array}{l}\text { The circular shapes with the different } \\
\text { and varied rossettes were used as } \\
\text { straight frames. }\end{array}$ \\
\hline $\begin{array}{l}\text { The calligraphic } \\
\text { streaks }\end{array}$ & The kufi and thulus calligraphy spreaded & $\begin{array}{l}\text { The rarety of Quran calligraphy in this } \\
\text { period }\end{array}$ \\
\hline $\begin{array}{ll}\text { The place } & \text { of } \\
\text { decorations } & \text { in } \\
\text { architecture } & \end{array}$ & $\begin{array}{l}\text { The building façade and most of the inner } \\
\text { and outer parts of the wall }\end{array}$ & $\begin{array}{l}\text { The facades specially the entries and the } \\
\text { guests sittings. }\end{array}$ \\
\hline Plaster colouring & $\begin{array}{l}\text { The plaster elements were coloured to } \\
\text { show the decoration units }\end{array}$ & $\begin{array}{l}\text { The shapes were not coloured, keeping } \\
\text { the main colour of the raw material }\end{array}$ \\
\hline $\begin{array}{l}\text { The plaster } \\
\text { architectonic elements }\end{array}$ & $\begin{array}{l}\text { Different architectonic elements were } \\
\text { decorated with plaster such as, the } \\
\text { minarets, the domes and the arches, and it } \\
\text { was mixed with other materials as wood } \\
\text { and mosaics }\end{array}$ & $\begin{array}{l}\text { The arches' frames were decorated in } \\
\text { broken method. }\end{array}$ \\
\hline The arches & $\begin{array}{l}\text { They took the shape of horseshoe arches, } \\
\text { and pointed arches with dropping } \\
\text { Stalactites, and also broken arches }\end{array}$ & $\begin{array}{l}\text { They took the shape of horseshoe } \\
\text { arches, and Najdi pointed arches, and } \\
\text { broken arches }\end{array}$ \\
\hline
\end{tabular}

The results: The spirit of the Idrisis' beginning headed from the south of the Arabian Peninsula towards Far Morocco, bearing its culture and its Najdi heritage arts with it, and established its basis in Far Morocco. 
There was a relationship that connected both the eastern and western Idrisid states despite their difference in place and time, as about a century separates them. However, the land and sea crossings played a role in extending the Idrisi's supervision through trade and cultural exchange as their beliefs and their religious and political ideologies mingled with the tribal, heritage, cultural legacies. This was reflected in the way they handled the facades of their palaces, which were characterized by simplicity, abstraction, and avoiding the drawing of living creatures, even if they were abstract wall decorations. They were also known for their austerity, and their buildings seemed plain, without exaggeration in spaces or wall decoration, as illustrated in details in the previous table (fig. 17).

Discussion: The second century AH witnessed many political movements in Arab Morocco; there was the Idrisid State in Far Morocco in the $5^{\text {th }}$ HG/ $11^{\text {th }}$ AH century, the Ibadi State in Tunisia, the Rustamids in (144 AH) in Middle Morocco, and the Aghlabids State in (188 AH), which was politically subordinate to the Abbasids but self- governing as a state for the Tulunids in Egypt. Then, the Fatimids succeeded in establishing their state in the fourth Hijri century, and then headed towards Cairo. During this period of time, while the Abbasid Caliphate was collapsing, the Ottoman Empire expanded eastward, keen on dominating Hijaz and Al Sham states (Levant states) and the land and sea trade routes.

Conclusion: The study traced the factors of the formation of Far Morocco Idrissids in the Arab Morocco in the (5 $5^{\text {th }}$ $\mathrm{AH} / 11^{\text {th }} \mathrm{AD}$ ) century and the emirate of Ashraaf Idrisids of Tihama 'Asir in Sebya during the (14 $\left.4^{\text {th }} \mathrm{AH} / 20^{\text {th }} \mathrm{AD}\right)$ century, showing the struggle of the two states for staying independent of the Caliphate, such as the Idrisid State of Fez that resisted the domination of the Abbasid Caliphate, the Aghlabids of Tunisia, the Fatimids, the Umayyads, and the Andalusians as well as the emirate of Ashraaf Idrisids in Sebya that resisted the Ottoman Caliphate, the first Saudi State, and the Zaidis in Yemen. The goal of the Idrisids was to restore the Islamic Caliphate as they are descendants of the Hashemi House. We have concluded through research and analysis that there may be a connection between the two eastern and western states, through immigration and the expansion of the Ashraaf descendants despite the difference in time and place, by studying the natural strategic crossings and the political circumstances that contributed in transmitting the influences of Far Moroccan arts to Sebya Region, south west kingdom of Saudi Arabia, which in turn contributed in enriching the arts of plaster decorations for the facades of Ashraaf al'adarisih palaces and their mingling with the Najdi Yemeni artistic local character as they shared almost similar and close features in that the decorations of both regions were devoid of animalistic and humanistic elements, even modified ones. Although both were influenced by Persian and Byzantine art styles, the elements of their decorations depended on geometric and plant abstraction and sometimes symbols of warding off magic.

Recommendation:- Interest in the study of Islamic decorative arts and development in line with the modern era, especially after it is located after the status of the architectural arts in the Arab Islamic civilization, reached its peak in the seventh and eighth centuries east and west, but in the middle of the thirteenth century was neglected and neglected and the focus was on quotations from the arts west.

-Studying the relationship between the architecture of the arts of Morocco and the south of Saudi Arabia, where it weakens the references that deal with the historical, political and artistic relationship between them, the researcher adopted through reading the writings of the Arab travelers to connect them.

\section{Previous studies.}

\section{Books:}

1. Ismail, Osman Osman: 1992, History of Islamic Architecture and Applied Arts in the Far East, Islamic Civilization Series, First Edition.

2. Al-Tha'albi, Abd al-'Azzi: 1990, North African History from the Islamic Conquest to the End of the Majority State, Second Edition, Beirut-Lebanon, Dar al-Gharb al-Islami.

3. Al-Aqili, Mohammed bin Ahmed, 1982, Al-Makhlaf Sulaimani, Dar al-Yamamah Publications, Riyadh, I, c.

4. Al-Omari: Shahab al-Din Ahmed bin Fadl, 1972, Pathways of sight in the kingdoms of Amasar, investigation: Ayman Fouad Sayed, Dar Al-Aitasam, Cairo.

Kunl, Ernst: 1966, Islamic Art, translated by Dr. Ahmed Issa, second edition.

6. Al-Maddah, Amira Ali, 2007, Al-Makhlaf Sulaimani under the rule of Al-Adarsa and King Abdul Aziz's efforts to annex the Makhlaf to the Kingdom of Saudi Arabia (Jazan region), Cairo, i.

7. Marzouk, Ali Abdulla: 2010, book (art of decoration of traditional architecture in Aseer, art and aesthetic study), series of archaeological studies, No. 8, the Saudi Commission for Tourism and Archeology (Archeology and Museums), Saudi Arabia. 


\section{Articles, periodicals and encyclopedias:}

1. Adrissi: Muhammad ibn Muhammad ibn 'Abd Allah, without history, Nazah al-Mushtaq in mentioning the places, countries and countries (d.m.t).

2. Baldari, John, 1980, Foreign Powers and Privileges in the Emirate of Idrissi, Center for Gulf Studies, i.

3. Hassan, Mohamed Abdel Ghani: 1971, Sherif Idrisi (the most famous geographical Arabs and Islam), the series of Arab flags, number 97, the General Authority for Publishing and Publishing.

4. Khalid Abdul Aziz Al-Dayel, "The Historical Report on the Excavations of Domat Al-Jandal in the Season 1405-1985". pp. 80-81.

5. Abdullah bin Mesfer, 1978, Al-Siraj Al-Munir in the biography of Amara Asir, 1, Al-Resala Foundation, Syria.

6. Abdullah Saad Al-Rashed and Dr. Mohammed Al-Thunayan et al., (1421/2001)"An Initial Report on the Survey of the Old Commercial Road: The High Yemeni Pilgrimage Road - Al-Najdi - Season Two", an article in the Yearbook of Ruins, Saudi Arabian Antiquities Yearbook, General Department of Antiquities and Museums, Ministry of Education, Saudi Arabia. , Sixth issue, tenth, Riyadh: pp. 106.

7. Ali Ali Hassan Al-Amayra (Research entitled: Elements of Composition and Visual Evaluation in Architecture) in Tishreen University Journal for Studies and Scientific Research (Engineering Sciences Series) Vol. (16) No. (2) for 1994, Page / $111-73$.

8. Massoud Al-Maeed, article at the conclusion of the Hilla Al-Omran Project in a broad international and local presence, "Ancient Asir Homes Inspires Photographers and Designers", Al Watan Online, Asir Printing and Publishing, Saudi Arabia, 22/2/2012.

9. Malkawi, Hanan Sulaiman: 1977, Relations between the Principals of Adarsa in Asir and the Supervision of Mecca, 1908-1925, Publications of the Committee of the History of Jordan, Edition 1.

\section{Foreign References:}

1. Ebin Saleh. Mohammed Abdullah, 2001. The decline vs the rise of architectural and urban forms in the Vernacular villages of southwest Saudi Arabia, College of Architecture and Planning, King Saud University, Riyadh, Saudi Arabia, Journal, Building and Environment. N.36. pp. 89-107

2. Fletcher, B., Cruickshank, D., 1996. History of Architecture, $20^{\text {th }}$ ed. Architectural Press.

3. Hogarth, David Geory. 1921. A history of Arabia, Oxford University Press, London.

4. Malkawi, Hannan S. 2011, Abd al-Azeez of the Addaressah in Tuhama Other (1920-1934), Jordan Journal of Social Sciences (JJSS), N. 38, Ed.1

5. Old, Clive Leather. 1983. The Britain of Saudi a 1925-1939, First Edition.

\section{References:}

1-Dabouz, Mohamed Ali: (2010), History of the Maghreb, Part I, printed by the Foundation of Tawa Latt, Algeria, first edition, p. 361. 2-Tamsneh: Located in Morocco, the area between the Bourgraq and Um El Rabie rivers.

3-Mawns, Hussein: (2000 AD), Landmarks of the History of Morocco and Andalusia, Cairo, Al-Rashed, I, Volume 5, p. 65.

4-Hassan, Mohamed Abdel Ghani, Sherif Idrisi (the most famous geographic Arabs and Islam), the series of Arab flags, number 97, Cairo: the General Authority for Publishing and Publishing,

5-Al-Obeidi, Iman Mahmoud Hammadi; and Dulaimi, Latif Khalaf Muhammad, (April 2016), the cultural data exchanged between Iraq and Andalusia, Journal of the Arts, Literature, Humanities and Sociology, Issue 5, published research, Emirates College of Educational Sciences, United Arab Emirates, Dubai.

6-Ismail, Osman Osman, History of Islamic Architecture and Applied Arts in Morocco, al-Aqsa, First Edition, Morocco: Series of Islamic Civilization of the West, 1992, p. 366.

7-Abdullah bin Ibrahim Al Omair, Traditional Architecture in Najd, Archaeological Studies, Issue 4, Riyadh: Issued by the Saudi Society for Archaeological Studies, 2007, p. 152:153.

8-Abdullah bin Ibrahim Al-Omair, 2007, op. Cit., P. 154:155. 